University of Nebraska - Lincoln

DigitalCommons@University of Nebraska - Lincoln

US Army Research

U.S. Department of Defense

2007

\title{
Weak Base Dispiro-1,2,4-Trioxolanes: Potent Antimalarial Ozonides
}

Yuanqing Tang

College of Pharmacy, University of Nebraska Medical Center, 986025 Nebraska Medical Center, Omaha, $N E, U S A$

Yuxiang Dong

College of Pharmacy, University of Nebraska Medical Center, 986025 Nebraska Medical Center, Omaha, $N E$, USA

Sergio Wittlin

Swiss Tropical Institute, Socinstrasse 57, CH-4002 Basel, Switzerland

Susan A. Charman

Victorian College of Pharmacy, Monash University, 381 Royal Parade, Parkville, Vic. 3052, Australia

Jacques Chollet

Swiss Tropical Institute, Socinstrasse 57, $\mathrm{CH}-4002$ Basel, Switzerland

See next page for additional authors

Follow this and additional works at: https://digitalcommons.unl.edu/usarmyresearch

Part of the Operations Research, Systems Engineering and Industrial Engineering Commons

Tang, Yuanqing; Dong, Yuxiang; Wittlin, Sergio; Charman, Susan A.; Chollet, Jacques; Chiu, Francis C. K.; Charman, William N.; Matile, Hugues; Urwyler, Heinrich; Dorn, Arnulf; Bajpai, Saroj; Wang, Xiaofang; Padmanilayam, Maniyan; Karle, Jean M.; Brun, Reto; and Vennerstrom, Jonathan L., "Weak Base Dispiro-1,2,4-Trioxolanes: Potent Antimalarial Ozonides" (2007). US Army Research. 23.

https://digitalcommons.unl.edu/usarmyresearch/23

This Article is brought to you for free and open access by the U.S. Department of Defense at DigitalCommons@University of Nebraska - Lincoln. It has been accepted for inclusion in US Army Research by an authorized administrator of DigitalCommons@University of Nebraska - Lincoln. 


\section{Authors}

Yuanqing Tang, Yuxiang Dong, Sergio Wittlin, Susan A. Charman, Jacques Chollet, Francis C. K. Chiu, William N. Charman, Hugues Matile, Heinrich Urwyler, Arnulf Dorn, Saroj Bajpai, Xiaofang Wang, Maniyan Padmanilayam, Jean M. Karle, Reto Brun, and Jonathan L. Vennerstrom 


\title{
Weak base dispiro-1,2,4-trioxolanes: Potent antimalarial ozonides
}

\author{
Yuanqing Tang, ${ }^{\mathrm{a}}$ Yuxiang Dong, ${ }^{\mathrm{a}}$ Sergio Wittlin, ${ }^{\mathrm{b}}$ Susan A. Charman, ${ }^{\mathrm{c}}$ Jacques Chollet, ${ }^{\mathrm{b}}$ \\ Francis C. K. Chiu, ${ }^{c}$ William N. Charman, ${ }^{c}$ Hugues Matile, ${ }^{d}$ Heinrich Urwyler, ${ }^{\mathrm{e}}$ \\ Arnulf Dorn, ${ }^{\mathrm{d}}$ Saroj Bajpai, ${ }^{\mathrm{a}}$ Xiaofang Wang, ${ }^{\mathrm{a}}$ Maniyan Padmanilayam, ${ }^{\mathrm{a}}$ \\ Jean M. Karle, ${ }^{f}$ Reto Brun ${ }^{b}$ and Jonathan L. Vennerstrom ${ }^{\mathrm{a}, *}$ \\ ${ }^{a}$ College of Pharmacy, University of Nebraska Medical Center, 986025 Nebraska Medical Center, Omaha, NE, USA \\ ${ }^{\mathrm{b}}$ Swiss Tropical Institute, Socinstrasse 57, CH-4002 Basel, Switzerland \\ ${ }^{\mathrm{c}}$ Victorian College of Pharmacy, Monash University, 381 Royal Parade, Parkville, Vic. 3052, Australia \\ ${ }^{\mathrm{d}}$ F. Hoffmann-La Roche Ltd., Grenzacherstrasse 124, CH-4070 Basel, Switzerland \\ ${ }^{\mathrm{e}}$ Basilea Pharmaceutica Ltd., Grenzacherstrasse 487, CH-4058 Basel, Switzerland \\ ${ }^{\mathrm{f}}$ Division of Experimental Therapeutics, Walter Reed Army Institute of Research, Washington, DC, USA
}

Received 23 October 2006; revised 30 November 2006; accepted 4 December 2006

Available online 15 December 2006

\begin{abstract}
Thirty weak base 1,2,4-dispiro trioxolanes (secondary ozonides) were synthesized. Amino amide trioxolanes had the best combination of antimalarial and biopharmaceutical properties. Guanidine, aminoxy, and amino acid trioxolanes had poor antimalarial activity. Lipophilic trioxolanes were less stable metabolically than their more polar counterparts.

(c) 2006 Elsevier Ltd. All rights reserved.
\end{abstract}

The discovery of artemisinin (ART) ${ }^{1}$ and its semisynthetic derivatives dihydroartemisinin (DHA), artemether (AM) and artesunate (AS) (Fig. 1) triggered ${ }^{2}$ the search for superior semisynthetic artemisinins ${ }^{3}$ and synthetic peroxide antimalarials. ${ }^{4}$

The first attempts to improve synthetic peroxide ${ }^{5}$ and semisynthetic artemisinin ${ }^{6}$ antimalarial specificity and biopharmaceutical properties by incorporating weak

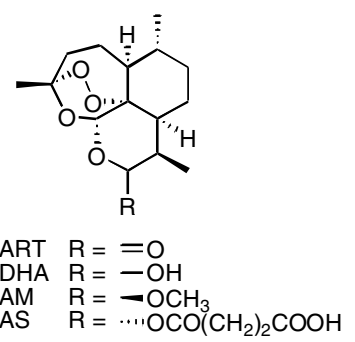

Figure 1. Artemisinin and its semisynthetic derivatives.

$\overline{\text { Keywords: }}$ 1,2,4-Trioxolanes; Secondary ozonides; Antimalarial; Peroxide; Artemisinin.

* Corresponding author. Tel.: +1 402559 5362; fax: +1 402559 9543; e-mail: jvenners@unmc.edu base functional groups and heterocycles were largely unsuccessful. Since that time, however, continued work $^{7-12}$ in this area has produced some encouraging results as illustrated by synthetic peroxides $1\left(\right.$ OZ209) ${ }^{13}$ and 2 (trioxaquine), ${ }^{14}$ and semisynthetic artemisinin 3 (artemisone) ${ }^{15}$ (Fig. 2). In this paper, we describe the synthesis ${ }^{16}$ and antimalarial properties of thirty $1,2,4-$ dispiro trioxolanes (secondary ozonides) containing azole heterocycles and aliphatic and aromatic amine functional groups. Metabolism and pharmacokinetic

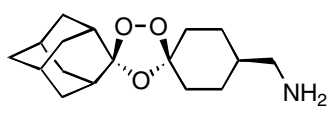

1<smiles></smiles>

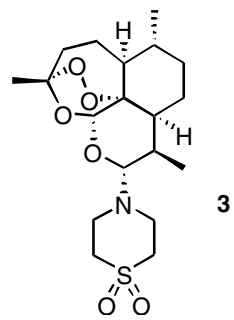

Figure 2. Weak base antimalarial peroxides. 


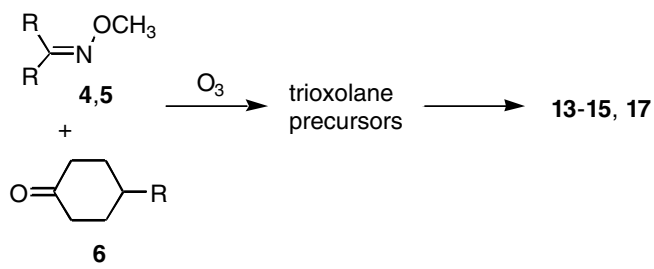

Scheme 1. Trioxolane synthesis by Griesbaum coozonolysis and postozonolysis transformations.

data are presented for selected trioxolanes. Our aim was to identify a potent weak base analog of $\mathbf{1}$ with high oral activity, good biopharmaceutical properties, and low toxicity.

Trioxolanes 13, 14, 15, and 17 were obtained by postozonolysis transformations of their precursor trioxolane esters and phthalimides; the latter were obtained by Griesbaum coozonolysis ${ }^{17,18}$ reactions between the $O$-methyl oximes of 2-adamantanone (4) or 4-tert-butyl cyclohexanone (5) (for 13) and the appropriate 4-substituted cyclohexanones 6 (Scheme 1). Symmetrical oxime ethers such as $\mathbf{4}$ preclude the syn-anti isomerism of the resulting carbonyl oxide intermediates, and ensure that the stereochemistry of the cycloaddition is only a function of the starting material ketones. For 4-substituted cyclohexanones, the major trioxolane isomers are uniformly cis with the substituent and peroxo groups at the equatorial and axial positions, respectively. ${ }^{19,20}$ With the exception of 31, each of the trioxolanes reported herein is single cis isomer. Indeed, X-ray crystallographic analysis ${ }^{21}$ of $7,{ }^{19}$ the phthalimide precursor of 14, reveals that it has a cis configuration (Fig. 3).

Alcohol 17 (96\%) was obtained by lithium borohydride/ lithium triethylborohydride ${ }^{22}$ reduction of its precursor methyl ester (cis). Conversion of $\mathbf{1 7}$ to its mesylate, followed by azide formation and triphenyl phosphine reductions afforded amine 15 (52\% overall). Azole $\mathbf{4 5}$ $(61 \%)$ was formed by treatment of the mesylate derivative of 17 with imidazole/NaH. Amines $13(65 \%)$ and $14(69 \%)$ were obtained by hydrazinolysis of their precursor phthalimides. Unlike amine 15, amines $\mathbf{1}$ and 14 were unstable as hydrochloride salts, but were quite stable as mesylate or tosylate salts.

Alkylation of 1 with 2-bromoacetamide and 2-chloropyrimidine in the presence of $\mathrm{K}_{2} \mathrm{CO}_{3}$ afforded $28(44 \%)$ and $36(20 \%)$ (Scheme 2). Carbamate $19(63 \%)$ and guanidine $20(56 \%)$ were obtained by treatment of 1 with ethyl chloroformate/ $\mathrm{Et}_{3} \mathrm{~N}$ and $1 H$-pyrazole-1-carboxamidine hydrochloride/ $\mathrm{Et}_{3} \mathrm{~N}$. Amine $27(55 \%)$ was obtained by reductive amination of formaldehyde with amine 1. Aminoxy trioxolane 18 (69\% overall) was obtained by Mitsunobu reaction of alcohol 8 with $\mathrm{N}$-hydroxyphthalimide followed by hydrazine deprotection. Reductive amination reactions were used to obtain amines $32(74 \%)$ and $31(45 \%)$ (1:1 mixture of $c i s$ and trans achiral diastereomers) from ketone 9 and amines $22(36 \%), 23(39 \%), 25(46 \%), 30(61 \%)$, and $34(49 \%)$ from aldehyde 10 (Scheme 2). Imidazole 41 (70\%) was obtained from 10 by treatment with $40 \%$ aq glyoxal followed by $7 \mathrm{~N}$ methanolic ammonia. Reaction of mesylate 11 with the anions of pyrazole and methyl 4-imidazole carboxylate afforded $\mathbf{3 9}(81 \%)$ and the isomeric imidazole ester precursors of $\mathbf{4 3}(20 \%)$ and $\mathbf{4 4}(47 \%)$. Successive treatment of these esters with $15 \% \mathrm{KOH}$, BOC anhydride, and $7 \mathrm{~N}$ methanolic ammonia afforded imidazole amides 43 (11\% overall) and 44 (27\% overall). Tetrazole 42 (69\% overall) was obtained by successive treatment of active ester $\mathbf{1 2}$ with 3-aminopropionitrile, trimethylsilyl azide/TPP/DIAD, sodium bicarbonate, and $1 \mathrm{M} \mathrm{HCl}$ according to the method of Johansson et al. ${ }^{23}$ Trioxolanes $1,7-12,16,21,24,26,29,33,35$, $\mathbf{3 7}, \mathbf{3 8}$, and $\mathbf{4 0}$ were obtained as previously described. ${ }^{19,20}$
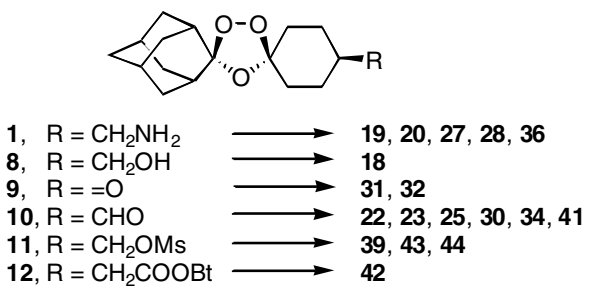

Scheme 2. Trioxolane synthesis via post-ozonolysis transformations.

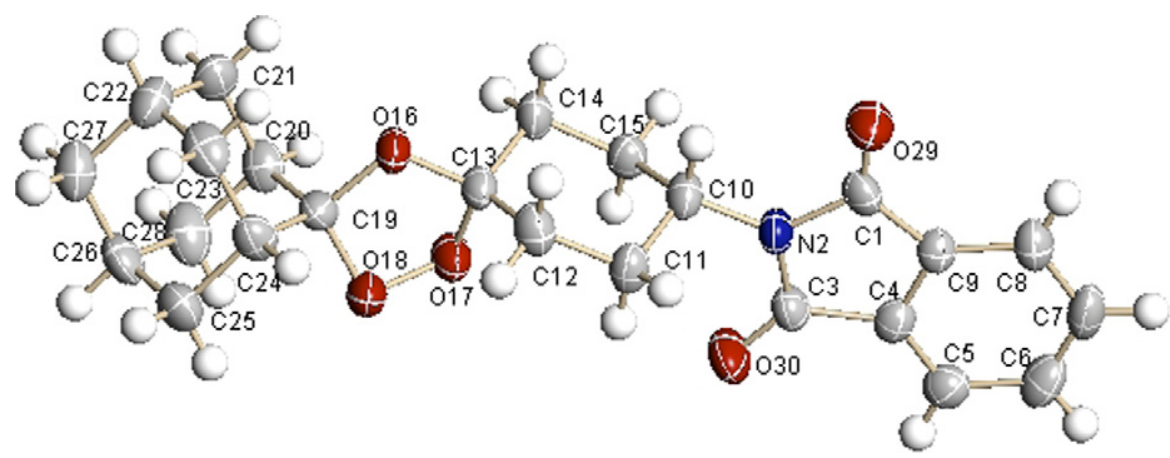

Figure 3. Ellipsoid plot of 7 showing the atom numbering used for the X-ray crystallographic report. The phthalimide and epoxide substituents are in equatorial positions on the cyclohexane ring, and the peroxide substituent is in the axial position. Displacement ellipsoids are shown at the $50 \%$ probability level. 
In vitro and in vivo antimalarial activities ${ }^{13}$ were measured using the chloroquine-resistant $\mathrm{K} 1$ and chloroquine-sensitive NF54 strains of Plasmodium falciparum, and Plasmodium berghei-infected mice, respectively. In vivo data were determined using single $10 \mathrm{mg} / \mathrm{kg}$ oral doses of the trioxolanes administered on day 1 post-infection in a non-solubilizing, standard suspension vehicle (SSV) formulation comprising $0.5 \% \mathrm{w} / \mathrm{v}$ carboxymethyl cellulose, $0.5 \% \mathrm{v} / \mathrm{v}$ benzyl alcohol, $0.4 \%$ $\mathrm{v} / \mathrm{v}$ Tween 80 , and $0.9 \% \mathrm{w} / \mathrm{v}$ sodium chloride in water. The complete lack of activity for $\mathbf{1 3}$ demonstrates the essential contribution of the spiroadamantane ring system to the antimalarial properties of $\mathbf{1}$ and its analogs. For the homologous series of primary amines 14, 1, and $\mathbf{1 5}$, in vitro potencies and metabolic stabilities were essentially invariant, but in vivo activity was the highest for $\mathbf{1}$ (Table 1). The primary alcohol isosteres $\mathbf{1 6 , 8}, \mathbf{8}$, and 17 were similarly potent in vitro, but were not as effective in vivo. The weaker in vivo activities of the alcohols may be due in part to their decreased metabolic stabilities (predicted hepatic ER > 0.5), presumably a function of their greater lipophilicities. The poor antimalarial profile of $\mathbf{1 8}$, the aminoxy isostere of $\mathbf{1 5}$, shows that a basic amino group is required for optimal antimalarial activity. On the other hand, the data for $\mathbf{2 0}$ show that substituting a more basic guanidine for the primary amine in $\mathbf{1}$ diminishes antimalarial potency by an order of magnitude. Ethyl carbamate 19, a potential prodrug of $\mathbf{1}$, had an antimalarial profile equal to that of $\mathbf{1}$, but was considerably less metabolically stable due, presumably, to hydrolysis of the carbamate functional group.

The data for secondary and tertiary aliphatic amines are depicted in Table 2. With the exception of amino acid 23, all of the secondary amines were quite potent $\left(\mathrm{IC}_{50 \mathrm{~s}}<1 \mathrm{ng} / \mathrm{mL}\right)$. Of these, only cyclopropyl amine $\mathbf{2 1}$ and diamine 26 had activities $<99.5 \%$. Data for aminoester 22, aminoacid $\mathbf{2 3}$, and aminoamide $\mathbf{2 4}$ show that $\mathbf{2 2}$ was rapidly metabolized (predicted hepatic ER > 0.99), probably by conversion to the metabolically stable $\mathbf{2 3}$, and that $\mathbf{2 4}$ provides an optimal combination of functional groups (amine, amide). Aminoamide 25, the homolog of $\mathbf{2 4}$, also had a very good antimalarial profile and had a metabolic stability similar to that of $\mathbf{2 4}$. Although tertiary amines $\mathbf{2 7}$ and $\mathbf{2 8}$ had good potency in vitro, they were not very active in vivo. When the tertiary amine was the proximal $\mathrm{N}$ atom of a piperazine heterocycle $(\mathbf{2 9}, \mathbf{3 0})$, in vivo activity improved substantially.

The data for secondary aromatic amines are depicted in Table 3. All of these had good potencies in vitro $\left(\mathrm{IC}_{50 \mathrm{~s}}\right.$ $<5 \mathrm{ng} / \mathrm{mL}$ ), and with the exception of 36, had in vivo activities $\geqslant 99.5 \%$. Anilides and sulfanilamides 31-34 were considerably more lipophilic $\left(\log \mathrm{D}_{\mathrm{pH}} 7.4>5\right)$ than their aliphatic amine counterparts shown in Table 2 . Not surprisingly, $\mathbf{3 1}$ and $\mathbf{3 2}$ were rapidly metabolized as was 34 (predicted ER >0.7). Interestingly, pyridine

Table 1. Lipophilicity, metabolic stability, and activity of primary amino trioxolanes and their alcohol and aminoxy isosteres, and carbamate and guanidine derivatives against $P$. falciparum in vitro and $P$. berghei in vivo

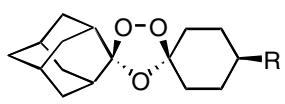

$1,10,14-20$

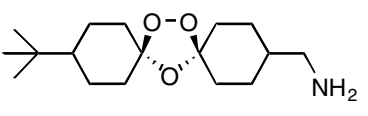

13

\begin{tabular}{|c|c|c|c|c|c|}
\hline Compound & $\mathrm{R}$ & $\log \mathrm{P} / \mathrm{D}_{\mathrm{pH}} 7^{\mathrm{a}}{ }^{\mathrm{a}}$ & $\mathrm{IC}_{50}{ }^{\mathrm{b}}(\mathrm{ng} / \mathrm{ml}) \mathrm{K} 1 / \mathrm{NF} 54$ & Activity $(\%)^{\mathrm{c}}$ & $E^{d}$ \\
\hline None & - & - & - & 0 & - \\
\hline $13^{\mathrm{e}}$ & - & $3.3 \mathrm{D}$ & $>100 />100$ & 0 & ND \\
\hline $14^{\mathrm{f}}$ & $\mathrm{NH}_{2}$ & $2.7 \mathrm{D}$ & $0.81 / 0.31$ & 98 & $<0.3$ \\
\hline $1^{\mathrm{e}}$ & $\mathrm{CH}_{2} \mathrm{NH}_{2}$ & $2.6 \mathrm{D}$ & $0.39 / 0.42$ & 99.98 & 0.24 \\
\hline $15^{\mathrm{g}}$ & $\left(\mathrm{CH}_{2}\right)_{2} \mathrm{NH}_{2}$ & 2.9D & $0.15 / 0.48$ & 99.08 & $<0.3$ \\
\hline $16^{\mathrm{h}}$ & $\mathrm{OH}$ & 3.9 & $0.25 / 0.51$ & 93 & 0.62 \\
\hline $8^{\mathrm{h}}$ & $\mathrm{CH}_{2} \mathrm{OH}$ & 5.1 & $0.83 / 0.20$ & 99.15 & 0.51 \\
\hline 17 & $\left(\mathrm{CH}_{2}\right)_{2} \mathrm{OH}$ & 5.6 & $0.30 / 0.75$ & 89 & 0.65 \\
\hline $18^{\mathrm{e}}$ & $\mathrm{CH}_{2} \mathrm{ONH}_{2}$ & $5.6 \mathrm{D}$ & $28 / 20$ & 47 & ND \\
\hline 19 & $\mathrm{CH}_{2} \mathrm{NHCO}_{2} \mathrm{CH}_{2} \mathrm{CH}_{3}$ & 6.2 & $0.40 / 0.56$ & 99.94 & 0.57 \\
\hline $20^{\mathrm{g}}$ & $\mathrm{CH}_{2} \mathrm{C}=\mathrm{NH}\left(\mathrm{NH}_{2}\right)$ & $1.2 \mathrm{D}$ & $6.2 / 7.6$ & 9 & ND \\
\hline $\mathrm{AM}^{\mathrm{h}}$ & - & 3.3 & $0.74 / 1.2$ & 99.36 & 0.89 \\
\hline $\mathrm{AS}^{\mathrm{h}}$ & - & 3.5 & $1.3 / 1.6$ & 67 & $0.43^{\mathrm{i}}$ \\
\hline
\end{tabular}

${ }^{a}$ Calculated as previously described, ${ }^{13,20} \log \mathrm{D}_{\mathrm{pH}} 7.4$ denotes the octanol/buffer partition coefficient at pH 7.4 which is relevant for the ionizable analogs.

${ }^{\mathrm{b}}$ Mean from $(n=2-3)$. Individual measurements differed by less than $50 \%$.

${ }^{\mathrm{c}}$ Groups of three $P$. berghei-infected MORO mice were treated orally one day post-infection with trioxolanes dissolved or suspended in SSV. Antimalarial activity was measured by percent reduction in parasitemia on day three post-infection. Individual measurements differed by less than $10 \%$.

${ }^{\mathrm{d}}$ Predicted hepatic extraction ratios (ER) using human liver microsomes. ${ }^{30}$

e Mesylate salt.

${ }^{\mathrm{f}}$ Tosylate salt.

${ }^{\mathrm{g}}$ Hydrochloride salt.

${ }^{\mathrm{h}}$ Data from Dong et al. ${ }^{25}$

${ }^{\mathrm{i}}$ Value for DHA, the primary metabolite of AS. 
Table 2. Lipophilicity, metabolic stability, and activity of secondary and tertiary amino trioxolanes against $P$. falciparum in vitro and $P$. berghei in vivo
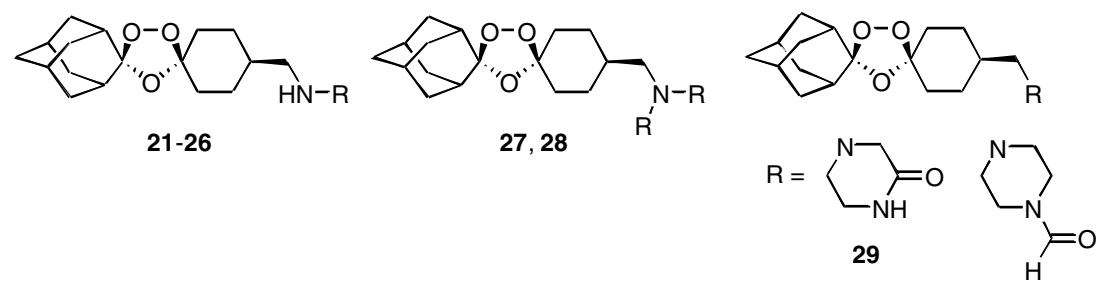

30

\begin{tabular}{|c|c|c|c|c|c|}
\hline Compound & $\mathrm{R}$ & $\log D_{\mathrm{pH}} 7.4$ & $\mathrm{IC}_{50}(\mathrm{ng} / \mathrm{ml}) \mathrm{K} 1 / \mathrm{NF} 54$ & Activity $(\%)$ & ER \\
\hline $21^{\mathrm{a}}$ & Cyclopropyl & 2.8 & $0.56 / 0.45$ & 59 & 0.33 \\
\hline $22^{\mathrm{a}}$ & $\mathrm{CH}_{2} \mathrm{COOEt}$ & 5.7 & $0.42 / 0.45$ & 99.64 & $>0.99$ \\
\hline $23^{\mathrm{a}}$ & $\mathrm{CH}_{2} \mathrm{COOH}$ & 2.5 & $11 / 17$ & 99.80 & 0.25 \\
\hline 24 & $\mathrm{CH}_{2} \mathrm{CONH}_{2}$ & 3.6 & $0.30 / 0.59$ & 99.67 & 0.40 \\
\hline $25^{\mathrm{a}}$ & $\left(\mathrm{CH}_{2}\right)_{2} \mathrm{CONH}_{2}$ & 2.4 & $0.41 / 0.91$ & 99.92 & 0.36 \\
\hline $26^{\mathrm{b}}$ & $\mathrm{CH}_{2} \mathrm{C}\left(\mathrm{CH}_{3}\right)_{2} \mathrm{NH}_{2}$ & 3.4 & $0.49 / 0.83$ & 95 & ND \\
\hline $27^{\mathrm{a}}$ & $\mathrm{CH}_{3}$ & 3.8 & $0.35 / 0.75$ & 74 & 0.34 \\
\hline 28 & $\mathrm{CH}_{2} \mathrm{CONH}_{2}$ & 3.8 & $1.7 / 2.0$ & 86 & ND \\
\hline 29 & - & 4.0 & $1.3 / 1.8$ & 99.81 & 0.50 \\
\hline 30 & - & 4.6 & $1.6 / 2.4$ & 99.01 & ND \\
\hline
\end{tabular}

${ }^{a}$ Mesylate salt.

${ }^{\mathrm{b}}$ Dimesylate salt.

Table 3. Lipophilicity, metabolic stability, and activity of aromatic amino trioxolanes against $P$. falciparum in vitro and $P$. berghei in vivo

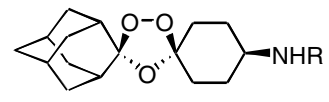

31, 32

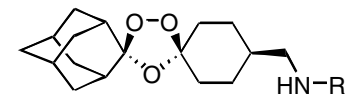

33-37

\begin{tabular}{|c|c|c|c|c|c|}
\hline Compound & $\mathrm{R}$ & $\log D_{\mathrm{pH}} 7.4$ & $\mathrm{IC}_{50}(\mathrm{ng} / \mathrm{ml}) \mathrm{K} 1 / \mathrm{NF} 54$ & Activity $(\%)$ & ER \\
\hline 31 & $4-\mathrm{CONH}_{2} \mathrm{C}_{6} \mathrm{H}_{5}$ & 6.2 & $1.1 / 1.0$ & 99.98 & 0.74 \\
\hline 32 & 4- $\mathrm{SO}_{2} \mathrm{NH}_{2} \mathrm{C}_{6} \mathrm{H}_{5}$ & 5.8 & $2.7 / 3.0$ & 99.98 & 0.73 \\
\hline 33 & $4-\mathrm{CONH}_{2} \mathrm{C}_{6} \mathrm{H}_{5}$ & 6.3 & $0.94 / 1.6$ & 99.73 & ND \\
\hline 34 & $4-\mathrm{SO}_{2} \mathrm{NH}_{2} \mathrm{C}_{6} \mathrm{H}_{5}$ & 5.9 & $2.0 / 3.0$ & 99.95 & 0.84 \\
\hline 35 & 3-Pyridyl & 5.4 & $0.25 / 0.34$ & 99.58 & ND \\
\hline 36 & 2-Pyrimidinyl & 5.3 & $0.65 / 1.2$ & 80 & ND \\
\hline $37^{\mathrm{a}}$ & 2-Thiazolyl & 6.4 & $2.3 / 2.2$ & 99.49 & ND \\
\hline
\end{tabular}

${ }^{\mathrm{a}}$ Mesylate salt.

35 and pyrimidine 36 were similarly potent in vitro, but the less basic $\mathbf{3 6}$ was much less active than $\mathbf{3 5}$ in vivo.

The data for the azoles are depicted in Table 4. With the exception of acidic tetrazole 42 , all had $\mathrm{IC}_{50 \mathrm{~s}}<2 \mathrm{ng} / \mathrm{mL}$. Compared to imidazole $\mathbf{3 8}$, the less basic pyrazole (39) and triazole (40) isosteres were equally potent in vitro, but only 40 was as active in vivo, and it was unexpectedly less stable metabolically. Compared to $N$-alkyl imidizole 38, the more polar 2-substituted imidazole 41 was more potent in vitro, but, it was much less active in vivo. Imidazoles 43 and 44 show that increasing the polarity of 38 by carboxamide substitution maintains antimalarial efficacy, but where measured (44), decreases metabolic stability. Imidazole $\mathbf{4 5}$ shows that extending the link between the cyclohexane and imidazole heterocycle increases lipophilicity but does not enhance antimalarial efficacy.

To assess whether some of the new weak base trioxolanes could cure $P$. berghei-infected mice, we adminis- tered a $3 \times 10 \mathrm{mg} / \mathrm{kg}$ divided dose on days $+1,+2$, and +3 post-infection. In this experiment, 1 was completely curative, semisynthetic artemisinins AM and AS provided no cures, ${ }^{13}$ and 24, 31, 32, and 38 cured 1/5, 2/5, 4/5, and $0 / 5$ of the infected mice, respectively.

Selected trioxolanes were administered intravenously (IV) and orally (PO) to rats ${ }^{24}$ and pharmacokinetic data for $\mathbf{1 , ~ 8 , ~ 2 4 , ~ 3 8 , ~ D H A , ~ a n d ~ A M ~ a r e ~ s h o w n ~ i n ~ T a b l e ~} 5$. The data indicated that alcohol $\mathbf{8}$ was rapidly cleared after IV dosing by conversion to its less active ${ }^{25}$ carboxylic acid metabolite. After PO dosing, plasma concentrations of $\mathbf{8}$ were not detected indicating very low oral bioavailability. Weak base trioxolanes 1, 24, and 38 each had a considerably longer half-life compared to $\mathbf{8}$ and oral bioavailabilities ranging from $30 \%$ to $60 \%$.

Preliminary toxicological investigations (5-day toxicity studies in male rats with daily oral administration) indicated toxicological profiles of $\mathbf{1 , 2 4}$, and $\mathbf{3 8}$ similar to that of artesunate, including gastric irritation, hepatocellular 
Table 4. Lipophilicity, metabolic stability, and activity of azole trioxolanes against $P$. falciparum in vitro and $P$. berghei in vivo

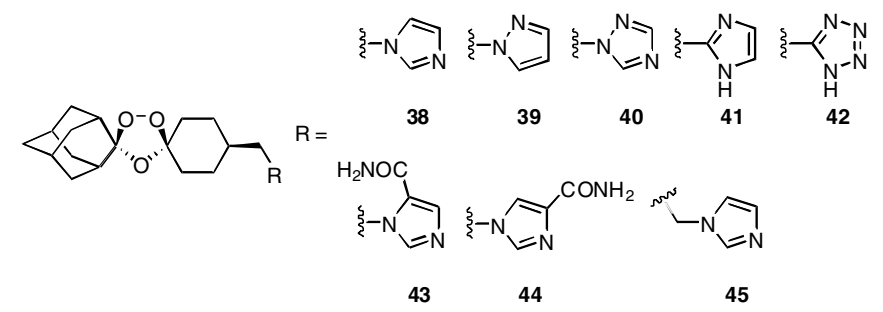

\begin{tabular}{|c|c|c|c|c|}
\hline Compound & $\log D_{\mathrm{pH}} 7.4$ & $\mathrm{IC}_{50}(\mathrm{ng} / \mathrm{ml}) \mathrm{K} 1 / \mathrm{NF} 54$ & Activity (\%) & ER \\
\hline $38^{\mathrm{a}}$ & 5.4 & $1.3 / 1.1$ & 99.78 & 0.23 \\
\hline 39 & 6.0 & $1.0 / 1.2$ & 78 & ND \\
\hline $40^{\mathrm{b}}$ & 4.9 & $0.90 / 1.7$ & 99.88 & 0.41 \\
\hline 41 & 4.9 & $0.29 / 0.42$ & 71 & ND \\
\hline 42 & 3.1 & $46 / 55$ & 40 & ND \\
\hline 43 & 5.0 & $0.58 / 0.97$ & 99.77 & ND \\
\hline 44 & 5.0 & $0.68 / 1.3$ & 99.76 & 0.89 \\
\hline 45 & 5.9 & $0.44 / 0.40$ & 99.82 & ND \\
\hline
\end{tabular}

${ }^{a}$ Hydrochloride salt.

${ }^{\mathrm{b}}$ Mesylate salt.

Table 5. Pharmacokinetic parameters ${ }^{\mathrm{a}}$ after intravenous and oral administration to rats

\begin{tabular}{lllll}
\hline \multirow{2}{*}{ Compound } & \multicolumn{2}{c}{ Intravenous administration } & Oral administration bioavailability (\%) \\
\cline { 2 - 4 } & Half-life (min) & Vol of distribution (L/kg) & Plasma clearance $(\mathrm{mL} / \mathrm{min} / \mathrm{kg})$ \\
\hline $\mathbf{1}$ & 150 & 39 & 177 & 31 \\
$\mathbf{8}$ & 27 & 5.3 & 136 & $\mathrm{nd}^{\mathrm{b}}$ \\
$\mathbf{2 4}$ & 94 & 13 & 60.1 & 58 \\
$\mathbf{3 8}$ & 47 & 4.1 & 72.0 & 36 \\
DHA $^{\mathrm{c}}$ & 26 & 3.0 & 114 & Not dosed PO \\
AM $^{\mathrm{c}}$ & 52 & 8.0 & 1.4 \\
\hline
\end{tabular}

${ }^{a}$ Values represent the average of 2-3 determinations.

${ }^{\mathrm{b}}$ nd, plasma concentrations were not detected following PO administration.

${ }^{\mathrm{c}}$ Data from Dong et al. ${ }^{20}$

hypertrophy, renal tubular changes, and atrophy of lymphatic tissues. No signs of neurotoxicity were seen. The overall toxicity of $\mathbf{2 4}$ and $\mathbf{3 8}$ was significantly lower than that of $\mathbf{1}$. Findings tended to be reversible at the end of a 1-week recovery period. Preliminary genotoxicity tests (Ames microsuspension ${ }^{26}$ and MNT in vitro ${ }^{27}$ assays) were not indicative of a relevant genotoxic or clastogenic/aneugenic potential. hERG patch-clamp assays revealed $\mathrm{IC}_{50}$ values of 1.8 and $2.7 \mu \mathrm{M}^{28}$ for $\mathbf{1}$ and $\mathbf{2 4}$, similar to those of 2.5 and $2.6 \mu \mathrm{M}^{29}$ for chloroquine and mefloquine.

In summary, compared to primary amino trioxolanes $\mathbf{1 4}, \mathbf{1}$, and 15, alcohol $(\mathbf{1 6}, \mathbf{8}, \mathbf{1 7})$ and aminoxy (18) isosteres, and guanidine (20) and amino acid (23) analogs had inferior antimalarial and biopharmaceutial profiles. As exemplified by imidazole 38, the good antimalarial profiles of several weak base azoles show that trioxolanes do not require an aliphatic amino functional group for high antimalarial activity. The reduced potency of $\mathbf{2 3}$ and $\mathbf{4 2}$ is consistent with our previous observation ${ }^{25}$ that trioxolane carboxylic acids have weak antimalarial activities. Although none of these new weak base trioxolanes had antimalarial profiles superior to that of $\mathbf{1}$, amino amides 24, 25, 29, and 31-34 were nearly as effec- tive; however each of these was less stable metabolically than 1. Indeed, lipophilic trioxolanes tended to be less stable metabolically than their more polar counterparts. Importantly, 1, 24, and 38 each displayed an improved half-life and oral bioavailability relative to DHA and $\mathrm{AM}$, and the latter $(\mathbf{2 4}, \mathbf{3 8})$ were less toxic than $\mathbf{1}$. Future studies will determine the potential of weak base trioxolanes as antimalarial drug development candidates.

\section{Acknowledgments}

This investigation received financial support from the UNDP/WORLD BANK/WHO Special Programme for Research and Training in Tropical Diseases (TDR ID No. 960275) and Medicines for Malaria Venture (MMV). We thank Danielle N. McClennan, Josefina Santo Tomas, Christian Scheurer, and Chistopher Snyder for technical assistance.

\section{References and notes}

1. Klayman, D. L. Science 1985, 228, 1049.

2. Ridley, R. G. Nature 2002, 415, 686. 
3. Li, Y.; Wu, Y.-L. Curr. Med. Chem. 2003, 10, 2197.

4. Tang, Y.; Dong, Y.; Vennerstrom, J. L. Med. Res. Rev. 2004, 24, 425 .

5. Vennerstrom, J. L. J. Med. Chem. 1989, 32, 64.

6. Lin, A.-J.; Li, L.-Q.; Klayman, D. L.; George, C. F.; Flippen-Anderson, J. L. J. Med. Chem. 1990, 33, 2610.

7. O’Neill, P. M.; Bishop, L. P.; Storr, R. C.; Hawley, S. R.; Maggs, J. L.; Ward, S. A.; Park, B. K. J. Med. Chem. 1996, 39, 4511 .

8. Li, Y.; Zhu, Y.-M.; Jiang, H.-J.; Pan, J.-P.; Wu, G.-S.; Wu, J.-M.; Shi, Y.-L.; Yang, J.-D.; Wu, B.-A. J. Med. Chem. 2000, 43, 1635.

9. Hindley, S.; Ward, S. A.; Storr, R. C.; Searle, N. L.; Bray, P. G.; Park, B. K.; Davies, J.; O’Neill, P. M. J. Med. Chem. 2002, 45, 1052.

10. Li, Y.; Yang, Z.-S.; Zhang, H.; Cao, B.-J.; Wang, F.-D.; Zhang, Y.; Shi, Y.-L.; Yang, J.-D.; Wu, B.-A. Bioorg. Med. Chem. 2003, 11, 4363.

11. Singh, C.; Malik, H.; Puri, S. K. Bioorg. Med. Chem. Lett. 2004, 14, 459.

12. Khac, V. T.; Van, T. N.; Van, S. T. Bioorg. Med. Chem. Lett. 2005, 15, 2629.

13. Vennerstrom, J. L.; Arbe-Barnes, S.; Brun, R.; Charman, S. A.; Chiu, F. C. K.; Chollet, J.; Dong, Y.; Dorn, A.; Hunziker, D.; Matile, H.; McIntosh, K.; Padmanilayam, M.; Santo Tomas, J.; Scheurer, C.; Scorneaux, B.; Tang, Y.; Urwyler, H.; Wittlin, S.; Charman, W. N. Nature 2004, $430,900$.

14. Robert, A.; Dechy-Cabaret, O.; Cazelles, J.; Meunier, B. Acc. Chem. Res. 2002, 35, 167.

15. Haynes, R. K.; Fugmann, B.; Stetter, J.; Rieckmann, K.; Heilmann, H.-D.; Chan, H.-W.; Cheung, M.-K.; Lam, W.-L.; Wong, H.-N.; Croft, S. L.; Vivas, L.; Rattray, L.; Stewart, L.; Peters, W.; Robinson, B. L.; Edstein, M. D.; Kotecka, B.; Kyle, D. E.; Beckermann, B.; Gerisch, M.; Radtke, M.; Schmuck, G.; Steinke, W.; Wollborn, U.; Schmeer, K.; Römer, A. Angew. Chem., Int. Ed. 2006, 45, 2082.

16. All new compounds provided satisfactory ${ }^{1} \mathrm{H}$ and ${ }^{13} \mathrm{C}$ NMR and elemental analysis data. Full experimental details can be found in: Vennerstrom, J.L.; Dong, Y.; Chollet, J.; Matile, H. Spiro and Dispiro 1,2,4-trioxolane antimalarials. U.S. Patent 6,486,199, 2002; Vennerstrom, J.L.; Tang, Y.; Dong, Y.; Chollet, J.; Matile, H.; Padmanilayam, M.; Charman, W.N. Spiro and Dispiro 1,2,4trioxolane antimalarials. U.S. Patent 6,825,230, 2004; Although we encountered no difficulties in working with these 1,2,4-trioxolanes (secondary ozonides), routine precautions such as the use of shields, fume hoods, and avoidance of metal salts should be observed whenever possible. Differential scanning calorimetry experiments revealed that these trioxolanes had good thermal stabilities; decomposition occurred at temperatures $>130{ }^{\circ} \mathrm{C}$ with enthalpies ranging from 320 to $660 \mathrm{~J} / \mathrm{g}$.

17. Griesbaum, K.; Liu, X.; Kassiaris, A.; Scherer, M. Liebigs Ann./Recueil 1997, 1381.

18. Griesbaum, K. Trends Org. Chem. 1997, 6, 145.

19. Tang, Y.; Dong, Y.; Karle, J. M.; DiTusa, C. A.; Vennerstrom, J. L. J. Org. Chem. 2004, 69, 6470.

20. Dong, Y.; Chollet, J.; Matile, H.; Charman, S. A.; Chiu, F. C. K.; Charman, W. N.; Scorneaux, B.; Urwyler, H.;
Santo Tomas, J.; Scheurer, C.; Snyder, C.; Dorn, A.; Wang, X.; Karle, J. M.; Tang, Y.; Wittlin, S.; Brun, R.; Vennerstrom, J. L. J. Med. Chem. 2005, 48, 4953.

21. Crystallographic data (excluding structural factors) for structure 7 in this paper have been deposited with the Cambridge Crystallographic Data Centre (CCDC) as supplementary publication number CCDC 298211. Copies of the data can be obtained, free of charge, on application to CCDC, 12 Union Road, Cambridge, CB2 1EZ, UK [fax: +44 (0)1223-336033 or e-mail: deposit@ ccdc.cam.ac.uk].

22. Brown, H. C.; Narasimhan, S. J. Org. Chem. 1982, 47, 1604.

23. Johansson, A.; Poliakov, A.; Åkerblom, E. A.; Wiklund, K.; Lindeberg, G.; Winiwarter, S.; Danielson, U. H.; Samuelsson, B.; Hallberg, A. Bioorg. Med. Chem. 2003, 11, 2551.

24. Compounds were dosed to male Sprague Dawley rats following an overnight fast. IV doses were administered via a cannula previously inserted into the jugular (cannulation on the day prior to dosing) and oral dosing was via gavage. Doses included $84 \mathrm{mg} / \mathrm{kg}$ IV in $40 \% \mathrm{v} / \mathrm{v}$ propylene glycol (PG), $10 \%$ v/v ethanol (EtOH), water and $10 \mathrm{mg} / \mathrm{kg}$ $\mathrm{PO}$ as a suspension in $0.5 \% \mathrm{w} / \mathrm{v}$ aqueous hydroxypropylmethyl cellulose (HPMC); $3810 \mathrm{mg} / \mathrm{kg}$ IV in $10 \% \mathrm{v} / \mathrm{v}$ PG, $10 \%$ v/v EtOH, water and $50 \mathrm{mg} / \mathrm{kg} \mathrm{PO}$ as a suspension in $0.5 \% \mathrm{w} / \mathrm{v}$ aqueous HPMC; $2425 \mathrm{mg} / \mathrm{kg}$ IV in aqueous citrate buffer, $\mathrm{pH} 3$, and $50 \mathrm{mg} / \mathrm{kg} \mathrm{PO}$ as a suspension in $0.5 \% \mathrm{w} / \mathrm{v}$ aqueous HPMC; $125 \mathrm{mg} / \mathrm{kg}$ IV in aqueous citrate buffer, $\mathrm{pH} 3$, and $50 \mathrm{mg} / \mathrm{kg} \mathrm{PO}$ as a suspension in $0.5 \% \mathrm{w} / \mathrm{v}$ aqueous HPMC; DHA $17 \mathrm{mg} / \mathrm{kg}$ IV in $0.1 \mathrm{M} \mathrm{Captisol}{ }^{\circledR}$. Sequential blood samples were collected through a cannula inserted in the carotid artery on the day prior to dosing. Blood samples were centrifuged immediately after sampling and plasma separated and stored at $-80^{\circ} \mathrm{C}$ prior to analysis by LC/MS. Concentrations were quantified by comparison to a calibration curve prepared in plasma and analyzed along with the study samples.

25. Dong, Y.; Tang, Y.; Chollet, J.; Matile, H.; Wittlin, S.; Charman, S. A.; Charman, W. N.; Santo Tomas, J.; Scheurer, C.; Snyder, C.; Scorneaux, B.; Bajpai, S.; Alexander, S. A.; Wang, X.; Padmanilayam, M.; Cheruku, S. R.; Brun, R.; Vennerstrom, J. L. Bioorg. Med. Chem. 2006, 14,6368

26. Maron, D. M.; Ames, B. N. Mutat. Res. 1983, 113, 173.

27. Albertini, S.; Miller, B.; Chetelat, A. A.; Locher, F. Mutat. Res. 1997, 392, 187.

28. Additional studies on the effects of $\mathbf{1}$ and $\mathbf{2 4}$ on cardiac function would be necessary for an interpretation of these data.

29. Traebert, M.; Dumotier, B.; Meister, L.; Hoffmann, P.; Dominguez-Estevez, M.; Suter, W. Eur. J. Pharmacol. 2004, 484, 41.

30. As fully described in reference ${ }^{13}$, compounds were incubated with human liver microsomes (BD Gentest, Discovery Labware Inc., Woburn, MA) at a substrate concentration of $1-10 \mu \mathrm{M}$ and a microsomal protein concentration of $0.4 \mathrm{mg} / \mathrm{mL}$. Loss of parent compound was monitored by LC/MS. 